\title{
Enhanced Expression of BiP Is Associated with Treatments that Extend Storage Longevity of Primed Tomato Seeds
}

\author{
Sunitha Gurusinghe, Ann L.T. Powell, and Kent J. Bradford ${ }^{1}$ \\ Department of Vegetable Crops, One Shields Avenue, University of California, Davis, CA 95616-8631
}

\begin{abstract}
ADDITIONAL INDEX WORDS. calcimycin, heat shock proteins, hydropriming, Lycopersicon esculentum Mill., osmopriming, tunicamycin, seed viability

Abstract. While seed priming (hydration in water or osmotic solutions followed by drying) enhances seed germination performance, the longevity of primed seeds in storage often is reduced. Postpriming treatments including a reduction in seed water content followed by incubation at 37 or $40{ }^{\circ} \mathrm{C}$ for $2 \mathrm{to} 4 \mathrm{~h}$ can substantially restore potential longevity in tomato (Lycopersicon esculentum Mill.) seeds. These conditions might induce heat-shock proteins (hsp) that could be involved in the extension of seed longevity. The abundance of BiP (78 kD Binding Protein), hsp70 and class I small hsp in primed seeds subjected to postpriming treatments was examined to assess this possibility. BiP mRNA and protein amounts increased during postpriming heat treatments that extended longevity of tomato seeds. Treatment of primed seeds with the calcium ionophore calcimycin (A21387) enhanced BiP protein accumulation in the absence of heat treatment and also extended potential seed longevity. Changes in the abundance of hsp70 and class I small hsps were not consistently associated with potential seed longevity. Thus, enhanced BiP expression may contribute to the improved longevity of primed seeds following postpriming treatments.
\end{abstract}

Seed priming is a process in which seeds are imbibed in water or osmotic solutions followed by drying before radicle emergence (McDonald, 2000). Priming can increase the speed and uniformity of germination when the seeds are subsequently planted (Taylor et al., 1998). However, primed seeds often exhibit reduced longevity in storage, particularly under adverse storage conditions (Alvarado and Bradford, 1988; Tarquis and Bradford, 1992). In some seeds, even relatively short hydration periods that do not advance germination can dramatically reduce storage longevity (Gurusinghe and Bradford, 2001; Tarquis and Bradford, 1992). Various treatments imposed after priming but before dehydration have been reported to improve seed longevity in storage (Bruggink et al., 1999). The most effective treatments included both a moderate reduction in seed moisture content and short periods of incubation at elevated temperature (Bruggink et al., 1999; Gurusinghe and Bradford, 2001; Schipper et al., 2001). This suggested that while seed longevity in storage was reduced by rapid dehydration following a period of hydration, a reduction in seed moisture content or exposure to elevated temperatures (heat shock) after priming might induce physiological or molecular changes that would render the seeds more resistant to deterioration during storage.

As exposure to high temperatures for only a few hours was effective in restoring longevity to primed seeds, induction of the heat-shock response is implicated. Cellular processes triggered by brief heat shock, such as the expression of heat-shock proteins (hsps), can increase tolerance to subsequent stresses (Wisniewski et al., 1996; Vierling, 1997). Some hsps function as molecular chaperones that assist in protein folding (DeRocher and Vierling, 1994; Lee et al., 1995; Vierling, 1997) and evidence suggests that

Received for publication 8 Jan. 2002. Accepted for publication 15 Apr. 2002. The authors thank Alan Bennett, University of California, Davis, for providing the tomato BiP cDNA and antibody, Choo Bong Hong, Institute of Molecular Biology and Genetics, Seoul National University, Korea for antibody to class I small heat shock proteins, Hiroyuki Nonogaki for assistance with protein immunoblotting, and Russell Wrobel for his constructive review of the manuscript. This study was supported by the Western Regional Seed Physiology Research Group and Regional Research Project W-168.

${ }^{1}$ Corresponding author; e-mail kjbradford@ucdavis.edu. small heat-shock proteins (shsps) cooperate with the large heatshock proteins such as hsp70 to reactivate heat-denatured proteins (Forreiter and Nover, 1998; Lee and Vierling, 2000). Plant hsps are expressed not only in response to heat stress, but also developmentally during embryogenesis and other stages of the life cycle (Schöffl et al., 1998). For example, several hsps accumulate to high amounts during seed development and have been implicated in the acquisition of desiccation tolerance during seed maturation (Helm and Abernethy, 1990; Reddy et al., 1998; Wehmeyer and Vierling, 2000).

Among the heat-shock family of proteins are specific chaperones that are capable of facilitating refolding of abnormally folded proteins, preventing protein aggregation, and binding to damaged proteins to aid entry into proteolytic pathways (Parsell and Lindquist, 1993; reviewed by Nover and Scharf, 1997). Among these, the immunoglobulin binding protein (termed BiP or GRP78) (Haas and Wable, 1983; Munro and Pelham, 1986) is an endoplasmic reticulum (ER)-resident homolog of cytoplasmic hsp70. Evidence indicates that BiP, in addition to being expressed constitutively in normal development (Dupont et al., 1998), is involved in protein repair processes in plants in response to heat shock and other stresses (Hurkman et al., 1998; Leborgne-Castel et al., 1999; Lee and Vierling, 2000). The maize floury-2 endosperm mutant overproduces BiP during abnormal protein accumulation associated with seed maturation, possibly reflecting a protein repair function (Fontes et al., 1991). BiP is also upregulated in response to ER stresses such as loss of calcium due to the ionophore calcimycin (also known as A21387) (Jones and Bush, 1991; Wooden et al., 1991; Li et al., 1993) or to the inhibition of glycosylation by tunicamycin, resulting in misfolded proteins (Fontes et al., 1991). BiP and other members of the hsp70 family have been reported to promote cellular survival when they are up-regulated following stress (Bolliger et al., 1994; LeborgneCastel et al., 1999; Kawana et al., 2000). In particular, expression of elevated levels of BiP in transgenic tobacco plants conferred tolerance to water deficit during growth and to inhibition by tunicamycin during seed germination (Alvim et al., 2001). Induction of $\mathrm{BiP}$ by partial or slow drying of primed seeds could 
ameliorate stresses incurred during dehydration and storage, possibly contributing to improved seed longevity.

We evaluated BiP and hsp expression in tomato seeds after priming and postpriming treatments in relation to seed longevity to test the hypothesis that genes involved in protein folding and repair pathways could contribute to the recovery of longevity induced by heat shock. Since calcimycin and tunicamycin can induce $\mathrm{BiP}$ and other chaperone proteins in the absence of heat shock, we further studied the effect of these compounds on BiP expression and on the longevity of primed seeds. We report here that elevation of $\mathrm{BiP}$ amounts, but not of hsp70 or class I shsps, in primed tomato seeds is correlated with treatments that extend seed longevity under controlled deterioration conditions.

\section{Materials and Methods}

SEED LOTS. Several lots of 'Moneymaker' cultivar of tomato (Lycopersicon esculentum Mill.) seeds produced in 1995-99 as described in Ni and Bradford (1993) were used in these studies. In some experiments, seeds of 'Spectrum 579' tomato cultivar obtained from Petoseed (now Seminis Vegetable Seeds, Oxnard, Calif.) were used.

Priming treatments. For hydropriming, tomato seeds were spread in a single layer $\left(\approx 20\right.$ seeds $\left./ \mathrm{cm}^{2}\right)$ in the dark on a single grade 628 germination blotter wetted with distilled water $(10$ $\left.\mathrm{mL} \cdot \mathrm{cm}^{-2}\right)$ in covered closed plastic boxes $(3 \times 10 \times 10 \mathrm{~cm})$ at 25 ${ }^{\circ} \mathrm{C}$. Seeds were imbibed in water for 20 to $24 \mathrm{~h}$ and withdrawn before radicle emergence. Seed moisture contents (MC) were $43 \%$ to $45 \%$ fresh weight basis (FWB). Following the hydration period, in some cases hydrated seeds were frozen immediately in liquid nitrogen and stored at $-80{ }^{\circ} \mathrm{C}$ for RNA and protein extractions. In other cases, seeds were rapidly dried in a ventilated oven for one day at $29^{\circ} \mathrm{C}$ to final MC of $8 \%$ to $9 \%$ FWB. Initial drying was rapid under these conditions, with loss of about half of the initial water content within the first $2 \mathrm{~h}$ of drying, and seed $\mathrm{MC}$ approached the final values within $6 \mathrm{~h}$. This hydropriming treatment did not result in the maximum advancement effect on germination attainable with more extended osmotic priming treatments, but was highly effective in reducing subsequent seed longevity in storage (Gurusinghe and Bradford, 2001). For osmopriming, seeds were imbibed on blotters as described above for $60 \mathrm{~h}$ in $-1.0 \mathrm{MPa}$ PEG 8000 at $20^{\circ} \mathrm{C}$. Seed moisture contents at the end of osmopriming were $41 \%$ to $45 \%$ FWB.

Postrriming treatments. For postpriming treatments, hydroprimed seeds or osmoprimed seeds (after rinsing off PEG in a Buchner funnel) were blotted to remove surface moisture and were placed in a ventilated oven without heat $\left(29^{\circ} \mathrm{C}\right)$ to lower their MC by $\approx 10 \%$ (e.g., $10 \mathrm{~g}$ of imbibed or osmoprimed seeds were dried until total weight reached $9 \mathrm{~g}$ ). For heat treatments, seeds were further incubated in closed magenta boxes at 37 or 40 ${ }^{\circ} \mathrm{C}$ for 1 to $4 \mathrm{~h}$ before rapid drying to $8 \%$ to $9 \% \mathrm{MC}$ as described above. Alternatively, seeds were thinly spread $\left(\approx 20\right.$ seeds $\left./ \mathrm{cm}^{2}\right)$ in 14-cm-diameter petri dishes on a No. 1 blotting paper wetted with $15 \mathrm{~mL}$ of $0.2 \mathrm{~mm}$ calcimycin solution (Calbiochem-Novabiochem Corporation, La Jolla, Calif.) or of 50 or $100 \mu \mathrm{g} \cdot \mathrm{mL}^{-1}$ tunicamycin solution (Sigma Chemical Co., St Louis, Mo.). Stock solutions were prepared by dissolving $5 \mathrm{mg}$ of calcimycin or tunicamycin in $1 \mathrm{~mL}$ of anhydrous dimethyl sulfoxide (DMSO) and then diluting with water before use. Calcimycin or tunicamycin solutions just covered the bottom surface of the seeds to allow seed aeration during incubation for 2 or $3 \mathrm{~h}$ at $25^{\circ} \mathrm{C}$ in the dark. Seeds were washed vigorously in distilled water for $2 \mathrm{~min}$ after incuba- tion to remove calcimycin before rapid drying to $8 \%$ to $9 \% \mathrm{MC}$. Experiments with postpriming treatments were repeated at least three times, except for the tunicamycin treatments, which were conducted twice.

CONTROLLED DETERIORATION. For controlled deterioration tests, seeds were brought to $12 \%$ to $13 \% \mathrm{MC}$ by incubation over saturated $\mathrm{NaCl}$ solution ( $75 \%$ relative humidity) at $2.5^{\circ} \mathrm{C}$ for 48 $\mathrm{h}$ in a closed vessel containing a fan for air circulation. Seeds ( $\approx 500$ seeds/treatment) with elevated MC were sealed in a glass bottle and submerged in a water bath at $50{ }^{\circ} \mathrm{C}$. Samples were removed after different aging periods and immediately tested for viability (see below). Sampling continued until viability was reduced below $50 \%$. Median viability period $\left(p_{50}\right.$, or controlled deterioration period required to reduce viability to $50 \%$ ) was determined by probit analysis using the SAS statistical package (SAS Institute Inc., Cary, N.C.).

Germination tests AND SEEDling EVAluations. Seeds were incubated in closed plastic boxes $(3 \times 10 \times 10 \mathrm{~cm})$ on two blotters wetted with $25 \mathrm{~mL}$ distilled water or in Petri dishes $(9 \mathrm{~cm}$ diameter) on a single grade 628 germination blotter wetted with $15 \mathrm{~mL}$ of distilled water. Each box or dish contained 20 to 25 seeds and two or three replicates were tested for each treatment and aging time. Seeds were incubated in the dark at $25^{\circ} \mathrm{C}$ for germination and then transferred to light and any abnormalities in the seedling growth were monitored in the same box or dish (water was added periodically as needed). Normal seedling percentages, evaluated according to Association of Official Seed Analysts rules (AOSA, 1992), were used to estimate $p_{50}$ values. As these seeds did not exhibit dormancy (initial germination percentages before controlled deterioration were close to $100 \%$ ), normal seedling percentages reflect total viability.

BiP mRNA EXPRESSION. A cDNA encoding the tomato BiP gene (accession L08830) in the pBluescript-II SK ${ }^{+}$vector was obtained from Alan Bennett, University of California, Davis (Meyer, 1995). An antisense RNA probe was generated using a DIG (digoxigenin; 11-2'-deoxy-uridine-5'-triphosphate)-labeled dNTP mixture (Boehringer Mannheim Corp., Indianapolis, Ind.) and T7 polymerase (Ambion, Inc., Austin, Texas) using the T7 promoter of the $\mathrm{pBS}-\mathrm{II} \mathrm{SK}{ }^{+}$vector. Total RNA was prepared from $1 \mathrm{~g}$ of wet or dried tomato seeds by a standard phenol extraction method (Sambrook et al., 1989). Equal quantities of RNA were separated on $1.3 \%(\mathrm{w} / \mathrm{v})$ agarose formaldehyde gels and transferred to neutral nylon membranes (Hybond-N, Amersham Pharmacia Biotech, Inc., Piscataway, N.J.). Hybridization was performed at $60{ }^{\circ} \mathrm{C}$ overnight in buffer containing $50 \%$ (v/v) deionized formamide, $5 \times \mathrm{SSC}, 0.1 \%(\mathrm{w} / \mathrm{v})$ sodium-lauroylsarcosine, $0.02 \%$ $(\mathrm{w} / \mathrm{v})$ sodium dodecylsulphate (SDS), $2 \%(\mathrm{w} / \mathrm{v})$ blocking reagent (Boehringer Mannheim) and $0.1 \mathrm{mg} \cdot \mathrm{mL}^{-1}$ salmon sperm DNA. The membranes were quickly rinsed thrice with $2 \times \mathrm{SSC}$ with $0.1 \%(\mathrm{w} / \mathrm{v}) \mathrm{SDS}$ and then shaken for $20 \mathrm{~min}$ at $60{ }^{\circ} \mathrm{C}$ and twice for $20 \mathrm{~min}$ at $60{ }^{\circ} \mathrm{C}$ with $0.2 \times \mathrm{SSC}, 0.1 \%$ (w/v) SDS. After washing, the membranes were rinsed in $0.1 \mathrm{M}$ maleic acid buffer, $\mathrm{pH} 7.5$, including $0.15 \mathrm{~m}$ sodium chloride and $0.3 \%(\mathrm{w} / \mathrm{v})$ Tween20 (buffer A), then blocked with $4 \%$ (w/v) blocking reagent in buffer A for $30 \mathrm{~min}$. The membranes were incubated $1 \mathrm{~h}$ with antiDIG alkaline phosphatase conjugate (Boehringer Mannheim) diluted 1:20,000. The membranes were quickly rinsed three times and then shaken thrice for $10 \mathrm{~min}$ in buffer $\mathrm{A}$ and an additional 10 min in detection buffer (100 mm Tris-HCl, pH 9.5, with $100 \mathrm{~mm}$ $\mathrm{NaCl}$ ). Signals were detected on film using chemiluminescent alkaline phosphatase substrate (CDP-Star, Ambion).

SDS-PAGE AND IMMUNOBLOTTING. For protein extraction, 20 
whole 'Moneymaker' seeds were homogenized in $0.5 \mathrm{~mL}$ of 50 mм K-phosphate buffer ( $\mathrm{pH}$ 6.8) in a chilled mortar and pestle. Alternatively, 100 radicle tips in $0.2 \mathrm{~mL}$ of buffer or 150 micropylar tissues (radicle tips including the surrounding endosperm) in $0.5 \mathrm{~mL}$ buffer were extracted for 'Spectrum' seeds. The homogenate was centrifuged at $13,000 g_{\mathrm{n}}$ for $2 \mathrm{~min}$ and protein content of the supernatant was measured spectrophotometrically using the Bio-Rad protein assay with a microplate reader. The supernatant proteins (representing $180 \mathrm{mg}$ dry seeds or $150 \mathrm{mg}$ wet seeds or $100 \mathrm{mg}$ dry caps per lane) were separated by electrophoresis in a 10\% SDS-polyacrylamide gel (Davis, 1964; Laemmli, 1970). Protein extracts were blotted from gels onto PVDF membranes (Immobilon-P; Millipore Corporation, Bedford, Mass.) for $1 \mathrm{~h}$ at $0.8 \mathrm{~mA} \cdot \mathrm{cm}^{-2}$ in semidry gel-blot transfer equipment using transfer buffer ( $39 \mathrm{~mm}$ glycine, $48 \mathrm{~mm}$ Tris, $0.0375 \%$ SDS and 20\% methanol). Subsequently, the membranes were blocked with $5 \%(\mathrm{w} / \mathrm{v})$ nonfat dry milk powder in phosphate-buffered saline (PBS) with Tween 20 (PBST) and then incubated by adding primary antibody (1:3000 dilution) for $3 \mathrm{~h}$ at $27^{\circ} \mathrm{C}$ followed by washing in PBST $(3 \times 5 \mathrm{~min})$. The stringency of this procedure was further refined to detect a single protein band by blocking in PBS with 5\% (w/v) nonfat dry milk powder in PBS for $20 \mathrm{~min}$ and then incubating with the primary antibody (dilution of 1:1000 for BiP and 1:10,000 for shsp and hsc70/ hsp70) overnight at $20{ }^{\circ} \mathrm{C}$ followed by PBST washings $(7 \times 5$ $\mathrm{min}$ ). Polyclonal primary antibodies were raised against a tomato $\mathrm{BiP}$ fusion protein containing the $\mathrm{C}$-terminal 72 amino acids of the BiP open reading frame (Meyer, 1995; kindly provided by Dr. Alan Bennett). On western blots, this antibody recognized a

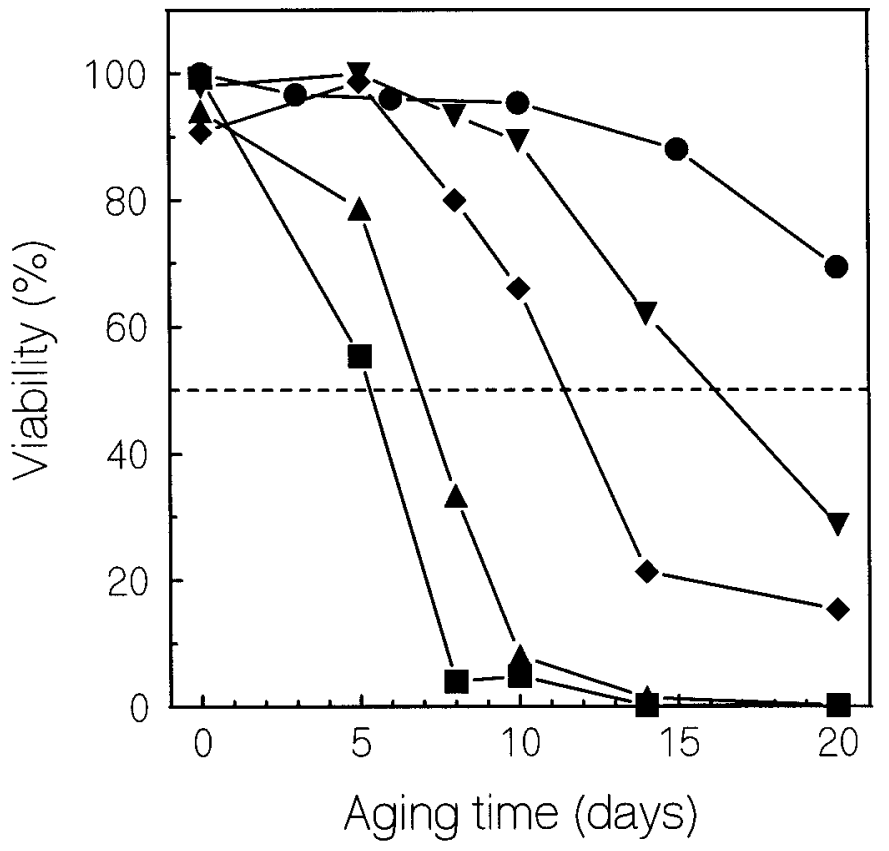

Fig. 1. Reduction in longevity of 'Moneymaker' tomato seeds due to $24 \mathrm{~h}$ hydropriming and the subsequent recovery of longevity due to postpriming heat-shock treatments at $37^{\circ} \mathrm{C}$. Seeds were either not primed (O) or were imbibed in water for $24 \mathrm{~h}$ and rapidly dried (hydroprimed, $\mathbf{0})$. Alternatively, following imbibition for $24 \mathrm{~h}$ the seed moisture content was reduced from $43 \%$ to $46 \%$ to $40 \%$ to $43 \%$ fresh weight basis and seeds were either rapidly dried $(\boldsymbol{\Delta})$, or they were incubated for $3 \mathrm{~h}(\boldsymbol{\nabla})$ or $4 \mathrm{~h}(\boldsymbol{\nabla})$ at $37^{\circ} \mathrm{C}$ before rapid drying ( 1 and $2 \mathrm{~h}$ durations not shown for clarity). Dried seeds of these treatments were subjected to controlled deterioration (incubation at $75 \%$ relative humidity and at $50{ }^{\circ} \mathrm{C}$ ), and viability was tested after different periods of aging. The $p_{50}$ is the duration of controlled deterioration required to reduce the viability to $50 \%$ (dashed line). tomato protein of $\approx 78 \mathrm{kD}$ which was enriched in the microsomal fraction of suspension-cultured tomato cells whereas a similar protein was not detected by the preimmune serum (Meyer, 1995). Antibody raised against human heat-shock protein 70/heat shock cognate 70 (hsp70/hsc70; StressGen Biotechnologies, Victoria, B.C., Canada) and an antibody that detects a conserved region common to plant class I shsps (courtesy of Choo Bong Hong, Institute of Molecular Biology and Genetics, Seoul National University, Korea) were also used in this study. Membranes were incubated with a 1:10,000 dilution of either goat-anti-rabbit or mouse-anti-human horseradish peroxidase conjugate (Bio-Rad Laboratories, Richmond, Calif.) in PBST for $1 \mathrm{~h}$ at $27^{\circ} \mathrm{C}$ or 0.5 $\mathrm{h}$ at $25^{\circ} \mathrm{C}$ (for higher stringency) followed by PBST-Tween-20 $(7 \times 5 \mathrm{~min}$ washes). The bands were visualized on $\mathrm{X}$-ray film after reaction with chemiluminescence reagent (Renaissance, DuPont, NEN Life Science Products Inc., Boston, Mass.). Each experiment was repeated at least twice with similar results.

\section{Results}

HEAT TREATMENTS INCREASE LONGEVITY OF PRIMED TOMATO SEEDS. Tomato seeds were hydroprimed (imbibed in water) for 24 $\mathrm{h}$ and either rapidly dried or subjected to postpriming heat-shock treatments. For the postpriming treatments, seeds were allowed to dry until they had lost $10 \%$ of their wet weight (to $40 \%$ to $43 \%$ MC, FWB) and then either rapidly dried (to $8 \%$ to $9 \% \mathrm{MC}$ ) or incubated at $37{ }^{\circ} \mathrm{C}$ for $1,2,3$ or $4 \mathrm{~h}$ before rapid drying (to $8 \%$ to $9 \% \mathrm{MC}$ ). Control (untreated) seeds and seeds from all treatments then were subjected to controlled deterioration to determine the effects of hydropriming and the postpriming heat treatments on potential longevity $\left(p_{50}\right)$. Control seeds had $p_{50}$ values of $24 \mathrm{~d}$ under controlled deterioration conditions, while seeds hydroprimed and rapidly dried or only subjected to $10 \%$ moisture loss before rapid drying had $p_{50}$ values of 6 to $7 \mathrm{~d}$ (Fig. 1). However, exposure to heat shock for $2 \mathrm{~h}$ or longer resulted in an increase in $p_{50}$ (Figs. 1-2). A 4-h postpriming heat treatment restored $p_{50}$ to $17 \mathrm{~d}$, more than double that of seeds treated similarly without the heat treatment.

BiP EXPRESSION IN RELATION TO SEED LONGEVITY. BiP protein was generally present at low amounts in control 'Moneymaker' seeds and primed seeds not exposed to heat treatments (Figs. 24). The increase in $p_{50}$ from 7 to 13 or $17 \mathrm{~d}$ due to $37^{\circ} \mathrm{C}$ heat treatment longer than $1 \mathrm{~h}$ was accompanied by $\mathrm{BiP}$ protein accumulation (Fig. 2). Similar results were obtained at $40{ }^{\circ} \mathrm{C}$, except that the maximum BiP protein content occurred after only $1 \mathrm{~h}$ of exposure and then decreased with longer incubations (Fig. 3). [Additional higher molecular weight bands detected in this blot were due to the stringency conditions used and could be completely eliminated by increasing the time of incubation in

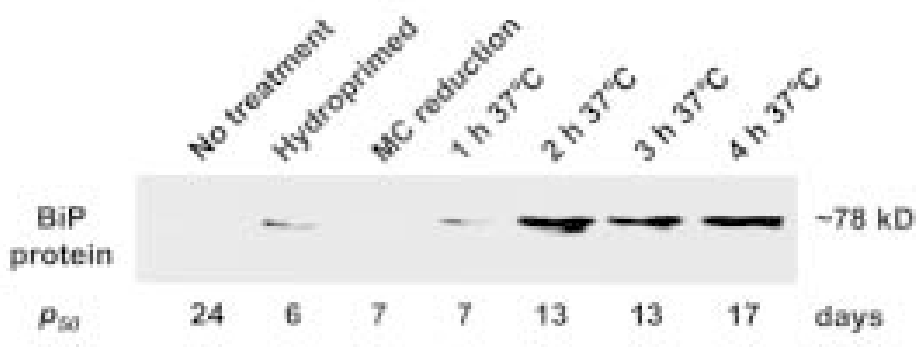

Fig. 2. BiP protein abundance in 'Moneymaker' tomato seeds before and after postpriming heat-shock treatments at $37^{\circ} \mathrm{C}$. Seeds were treated as described in Fig. 1. Protein extracts were separated on SDS-PAGE followed by immunoblotting with anti-BiP serum. Potential longevity $\left(p_{50}\right)$ of the seeds from each treatment during controlled deterioration is shown beneath the lanes. 
primary antibody with $5 \%$ milk to overnight combined with $0.5 \mathrm{~h}$ exposure to secondary antibody (see Figs. 2, 4, and 5).] The abundance of $\mathrm{BiPmRNA}$ also doubled during the first 1 to $2 \mathrm{~h}$ of heat treatment at $40{ }^{\circ} \mathrm{C}$ compared to primed seeds not exposed to heat treatments (Fig. 3). Three hours at $40{ }^{\circ} \mathrm{C}$ reduced both BiP mRNA and protein amounts compared to the first $2 \mathrm{~h}$ (Fig. 3). Although the correlation between the presence of $\mathrm{BiP}$ and extended longevity was not absolute, as hydroprimed and rapidly dried seeds with low $p_{50}$ values did contain some $\mathrm{BiP}$, the heat-treated seeds having higher $p_{50}$ values tended to have greater amounts of BiP protein (Figs. 2-3).

CALCIMYCIN INDUCES BiP EXPRESSION AND RESTORES LONGEVITY OF PRIMED SEEDS. Treatment of hydroprimed (and slightly dried by $10 \% \mathrm{MC}$ reduction) seeds for $2 \mathrm{~h}$ in $0.2 \mathrm{~mm}$ calcimycin induced the accumulation of BiP mRNA and protein comparable to the effect of heat treatment (Fig. 4). An extension of $p_{50}$ in both calcimycintreated and heat-treated seeds accompanied the increase in $\mathrm{BiP}$ protein expression (Fig. 4). The effectiveness of calcimycin treatment in extending $p_{50}$ and the corresponding increase in expression of BiP mRNA and protein were confirmed in two additional experiments with different 'Moneymaker' seed lots (data not shown). The $10 \%$ reduction in $\mathrm{MC}$ followed by $2 \mathrm{~h}$ imbibition in water (i.e., the control for the calcimycin treatment) also caused some accumulation of BiP protein, but did not extend $p_{50}$ (Fig. 4). Rapid drying also influenced $\mathrm{BiP}$ mRNA or protein abundance following calcimycin or heat treatment. Rapid drying immediately after hydropriming did not induce $\mathrm{BiP}$ accumulation, but seeds dried rapidly after an initial $10 \%$ reduction in $\mathrm{MC}$ and rehydration for 2 $\mathrm{h}$ did accumulate BiP protein (Fig. 4). Rapid drying after heat treatment also appeared to reduce the amount of $\mathrm{BiP}$ protein compared to the amount present immediately after the heat treatment (Fig. 4).

EFFECTS OF POSTPRIMING TREATMENTS ON hsp70 AND SHSPS. In addition to $\mathrm{BiP}$, the abundance of two representative hsps, cytoplasmic hsp70/hsc70 and class I small hsps, was assessed in relation to priming and postpriming treatments. Cytoplasmic hsp70/hsc 70 was equally present in untreated, primed, heat-shocked and tunicamycintreated 'Spectrum' tomato seeds but was reduced in calcimycintreated seeds (Fig. 5A and B). In contrast, shsps were more abundant in untreated, heat-shocked and tunicamycin-treated seeds than in primed or calcimycin-treated seeds (Fig. 5A and B). Longevity was

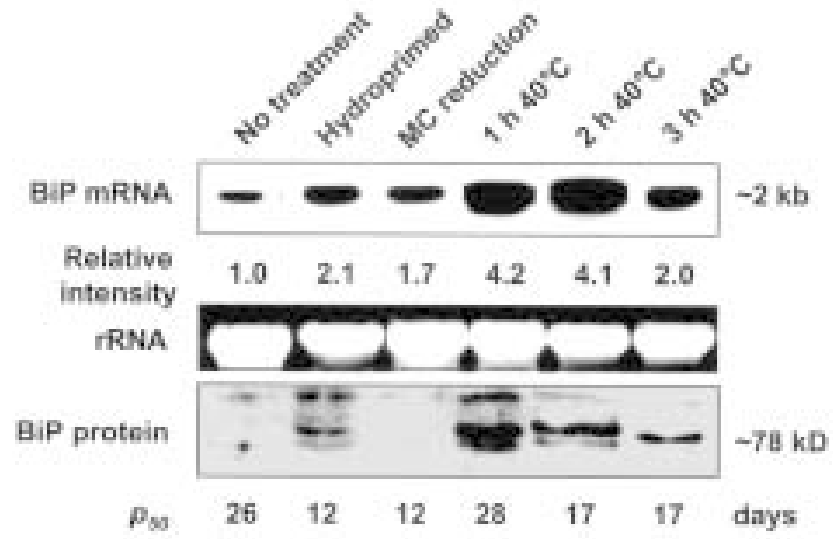

Fig. 3. BiP mRNA and protein abundance in dry 'Moneymaker' tomato seeds following hydropriming, MC reduction and 1,2 , or $3 \mathrm{~h}$ at $40^{\circ} \mathrm{C}$. Seed treatments are as described in Fig. 1. Relative intensities of mRNA hybridization with a tomato BiP riboprobe were normalized for RNA loading using the ribosomal RNA (rRNA) bands and are scaled by considering the lowest intensity as 1 . An immunoblot with anti-BiP serum shows $\mathrm{BiP}$ protein content in extracts from the same seeds. The $p_{50}$ values of each seed lot during controlled deterioration are indicated below the lanes. not as severely affected by osmopriming in these experiments as compared to the hydropriming treatments in Figs. 1-4. However, both heat-shock and calcimycin treatments doubled $p_{50}$ relative to the untreated control seeds in one experiment (Fig. 5B). Heat shock induced accumulation of both BiP and class I shsps, while calcimycin induced only $\mathrm{BiP}$, but both treatments extended longevity approximately equally (Fig. 5B), suggesting that $\mathrm{BiP}$ accumulation, rather than a general heat-shock response, was related to seed longevity.

\section{Discussion}

Seed priming is a commercially successful practice for improving seed germination performance, but reductions in seed storage life after priming have limited its application in some cases. Postpriming treatments have been identified that can extend longevity of primed seeds (Bruggink et al., 1999; Gurusinghe and Bradford, 2001; Schipper et al., 2001), and the experiments reported here confirm that tomato seed longevity can be restored by the combination of reducing seed MC slightly and then incubating at elevated temperature immediately following priming (Fig. 1). Heat treatments from 2 to $4 \mathrm{~h}$ at $37^{\circ} \mathrm{C}$ improved longevity (Figs. 1-2), while at $40{ }^{\circ} \mathrm{C}$ shorter treatments were more effective and the benefits decreased with longer exposure (Fig. 3). It is likely that at elevated temperatures a balance is achieved between the intensity and length of treatment sufficient to induce a beneficial effect on longevity of primed seeds versus damage induced during extended exposure to high temperature.

The mechanisms underlying both the reduction in storage life due to priming and its restoration by postpriming treatments remain unknown. Deterioration of dry seeds in storage results from complex interactions among many physical and biochemical factors, and multiple mechanisms to resist these changes are also likely to be present (Walters, 1998). The hypothesis has been proposed that

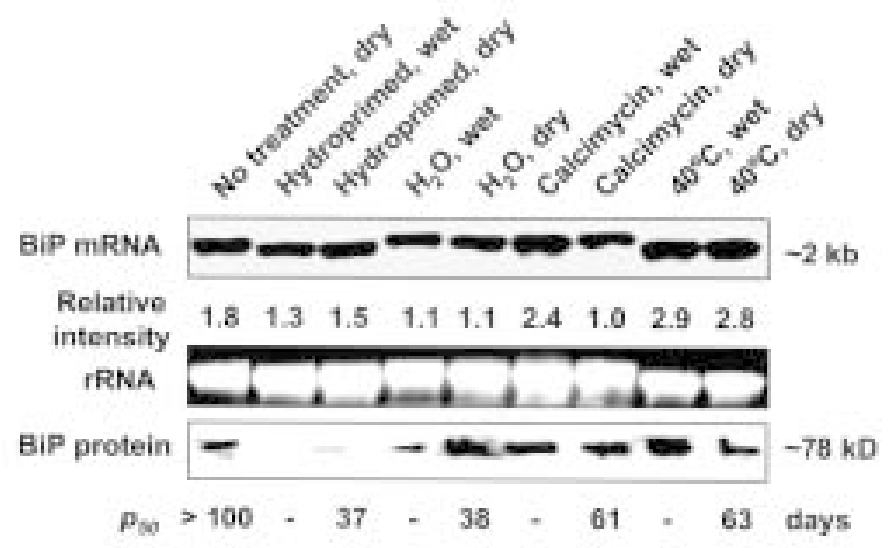

Fig. 4. BiP mRNA and protein abundance in hydrated or dried 'Moneymaker' tomato seeds following hydropriming and exposure to calcimycin or heat-shock at $40{ }^{\circ} \mathrm{C}$. Tomato seeds (no treatment, dry) were imbibed in water for $24 \mathrm{~h}$ at 25 ${ }^{\circ} \mathrm{C}$ and sampled for mRNA and protein both before (hydroprimed, wet) and after rapid drying to $8 \%$ to $9 \%$ moisture content (MC) (hydroprimed, dry). Seeds were also imbibed in water for $22 \mathrm{~h}$ at $25^{\circ} \mathrm{C}$ followed by $10 \% \mathrm{MC}$ reduction before reimbibition for another $2 \mathrm{~h}$ in water $\left(\mathrm{H}_{2} \mathrm{O}\right.$, wet $)$ or in $0.2 \mathrm{~mm}$ calcimycin (calcimycin, wet) and sampling. The remaining seeds were then rapidly dried and sampled, $\left(\mathrm{H}_{2} \mathrm{O}\right.$, dry; calcimycin, dry $)$. An additional subset of seeds imbibed for $22 \mathrm{~h}$ in water followed by $10 \% \mathrm{MC}$ reduction was incubated at $40{ }^{\circ} \mathrm{C}$ for 2 $\mathrm{h}$ and sampled either at the end of the heat treatment $\left(40^{\circ} \mathrm{C}\right.$, wet $)$ or after rapid drying $\left(40^{\circ} \mathrm{C}\right.$, dry). The intensities of mRNA hybridization to a tomato $\mathrm{BiP}$ riboprobe are normalized relative to the rRNA bands as described in Fig. 3. BiP protein abundance is indicated in the lower immunoblot panel. The $p_{50}$ values of each seed lot during controlled deterioration are indicated below the lanes (only dried seeds were tested). 
soluble oligosaccharides are involved in stabilizing membrane and protein structure and in promoting the formation of a highly viscous glassy state in dry seeds (e.g., Bernal-Lugo and Leopold, 1995; Leprince et al., 1993). However, specific changes in sucrose or oligosaccharide contents were not associated with the improved longevity of tomato and impatiens seeds induced by postpriming treatments (Gurusinghe and Bradford, 2001). Similarly, Bentsink et al. (2000) found no significant relationship between seed oligosaccharide content and seed longevity in recombinant inbred lines of Arabidopsis thaliana inherently differing in oligosaccharide content. Furthermore, Buitink et al. (2000) examined the intracellular glass stability of impatiens and pepper seeds before and after priming and could not detect any significant changes in relation to seed longevity. Thus, changes in seed oligosaccharide contents or in the stability of the glassy state are unlikely to account for the effects of postpriming treatments on seed longevity.

Features common to postpriming treatments that can restore seed longevity are a partial reduction in seed MC (or a slow rate of dehydration) and incubation at elevated temperatures before rapid drying (Bruggink et al., 1999; Gurusinghe and Bradford, 2001; Schipper et al., 2001). Thus, mechanisms that are involved in adaptation to water or heat stress may also be involved in extending seed longevity. Stabilization of protein structure is likely to be important for long-term survival in the dry state, and an inability to synthesize potential protective proteins, such as Lea- or dehydrinlike proteins, during rapid drying following hydration may result in protein destabilization (Wolkers et al., 1999). During drying, the stability of the secondary structure of several major proteins decreased more in seeds of desiccation-sensitive mutants of Arabidopsis than in desiccation-tolerant mutant or wild type seeds (Wolkers et

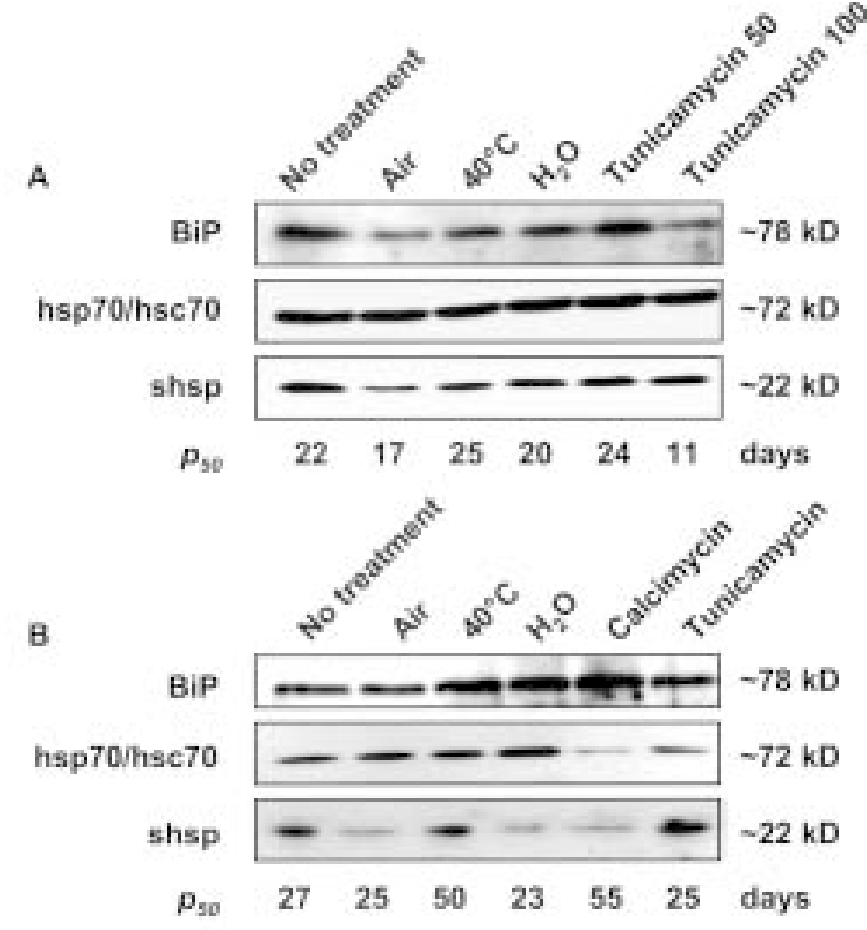

Fig. 5. Immunoblots illustrate BiP, hsp70/hsc70, and class I shsp protein abundance in extracts from dry endosperm caps and radicle tips $(\mathbf{A})$ or radicle tips $(\mathbf{B})$ of 'Spectrum' tomato seeds. Seeds were osmoprimed for $60 \mathrm{~h}$ in $-1.0 \mathrm{MPa}$ PEG 8000 at $20^{\circ} \mathrm{C}$ followed by reduction in MC from $41 \%$ to $45 \%$ to $38 \%$ to $42 \%$ fresh weight basis, then either held for another $2(\mathbf{A})$ or $3 \mathrm{~h}(\mathbf{B})$ at 20 or $40^{\circ} \mathrm{C}$ in air, or reimbibed in water or in $0.4 \mathrm{~mm}$ calcimycin or in $50 \mu \mathrm{g} \cdot \mathrm{mL}^{-1}(\mathbf{A})$ or 100 $\mu \mathrm{g} \cdot \mathrm{mL}^{-1}$ (A and $\mathbf{B}$ ) tunicamycin before rapid drying. The $p_{50}$ values of each seed lot during controlled deterioration are indicated below the lanes. al., 1998). Priming could also potentially increase the susceptibility of DNA to damage during storage by altering the abundance of specific proteins involved in maintaining DNA conformation and integrity during dehydration (Boubriak et al., 2000). For example, Chiatante and Onelli (1993) proposed that a nuclear-localized protein (QP47) could be involved in DNA structural organization and protection during seed dehydration and storage. Similarly, a specific H1-S histone gene in tomato was induced by water stress in tomato leaves (Bray et al., 1999) and was targeted to the nucleus, where it associated with chromatin (Scippa et al., 2000). Such higher-order organization and integrity of DNA might be important in dry seeds under storage, but could be lost during the activation of gene expression and/or DNA replication during seed imbibition or priming. Postpriming treatments may both induce and allow time for the accumulation of protective proteins before dehydration that would contribute to extended longevity in storage.

$\mathrm{BiP}$ is known to be involved in restoring the function of proteins damaged by heat or misfolding (Lee and Vierling, 2000), and may function as a chaperone in the preservation of protein structure during dehydration or in the reactivation of proteins damaged due to the imbibition and drying processes involved in seed priming. Heattreated tomato seeds contained more BiP mRNA and protein than hydroprimed seeds, which contained less or no detectable BiP protein (Figs. 2-4). Similarly, enhancement of BiP mRNA accumulation by heat has been reported in Xenopus embryonic development (Miskovic and Heikkila, 1999) and in a variety of fungi (van Gemeren et al., 1997; Techel et al., 1998). A specific heat shock element (HSE) is required in the promoter for induction of the heatshock genes during heat stress, where they function by binding the heat-shock transcription factor (HSF) (Wu et al., 1994). The presence of the HSE motif in the tomato BiP promotor (Meyer, 1995) is consistent with the induction of the tomato BiP gene by heat shock. $\mathrm{BiP}$ is also constitutively expressed in cells, and $\mathrm{BiP}$ protein abundance was variable in untreated control seeds that also exhibited high $p_{50}$ values (Figs. 2-4). During seed maturation, other protective mechanisms may be invoked so that high amounts of $\mathrm{BiP}$ are not essential for seed longevity. Once seeds are imbibed and protein synthesis is activated in the ER, enhanced BiP gene expression may contribute to adaptation to subsequent dehydration and maintenance of viability during storage. BiP accumulation alone, however, is apparently not sufficient to confer extended longevity, as the protein was detected in hydroprimed seeds that had short storage lives (Figs. 2-4).

A partial reduction in seed moisture content by at least $10 \%$ appears to be important in the restoration of longevity by postpriming treatments, even in osmoprimed seeds that are already below full hydration (Gurusinghe and Bradford, 2001; Schippers et al., 2001). In additional studies with a number of other species (lettuce, onions, pepper, broccoli and impatiens), we found that the most common factor in effective longevity-extending postpriming treatments was a moderate reduction in seed moisture content before rapid drying, regardless of heat-shock treatment (data not shown). A threshold moisture content reduction appeared to be essential in eliciting the effect, and there is evidence that hsps are induced by plant water stresses as well as by heat shock. In soybean, BiP genes were induced by both water-stress and heat-shock treatments (Figueiredo et al., 1997), and different BiP isoforms were differentially regulated in response to different stresses (Cascardo et al., 2000). In Arabidopsis thaliana, three hsp cognates (hsp70, hsp80, and ubiquitin) were strongly induced in water-stressed plants (Kiyosue et al., 1994) and hsp70 and ubiquitin were identified in waterstressed rice cells (Borkird et al., 1991). Interestingly, increased 
heat-stress tolerance in geranium induced by water stress was associated with the accumulation of several heat-stable, dehydrinlike proteins ( 25 to $60 \mathrm{kDa}$ ) and both cytosolic hsp70 and BiP (Arora et al., 1998). Both Hsp70 and shsps were present tomato seeds, but were not responsive to moderate $\mathrm{MC}$ reduction alone (Fig. $5 \mathrm{~A}$ and $\mathrm{B}$, air treatments). The amount of class I shsps detected increased due to heat shock, but little change was detected in hsp70/hsc70 abundance (Fig. $5 \mathrm{~A}$ and B, $40^{\circ} \mathrm{C}$ treatments). This could be because only specific members of the hsp70 family are responsive to heat shock while others are constitutively expressed (Nover and Scharf, 1997). Additional studies with more specific molecular probes will be needed to determine whether expression of specific hsp family members is induced by postpriming treatments.

As many different hsps are induced by heat shock, we used an alternative method that more specifically induces BiP to test whether it is involved in extending seed longevity. Calcimycin (or A23187), a calcium ionophore that causes depletion of $\mathrm{ER} \mathrm{Ca}^{2+}$ levels, is a potent inducer of BiP and related proteins (Jones and Bush, 1991; Wooden et al., 1991; Lievremont et al., 1997). The depletion of $\mathrm{Ca}^{2+}$ in the ER adversely affects normal protein folding, glycosylation, and subunit association; consequently, the ER recruits more BiP protein molecules along with other molecular chaperones such as Grp94 (Li and Lee, 1991; Li et al., 1992, 1993), Erp29 (Mkrtchian et al., 1998), Erp72 (Kuznetsov et al., 1997), and the calnexin/ calreticulin complex (Hebert et al., 1996). However, calcimycin did not increase BiP mRNA abundance in cultured tomato cells, although tomato BiP mRNA (but not that of other hsp70s) of cultured cells were increased by tunicamycin treatment (Meyer, 1995), as has been observed in other organisms (Watowich and Morimoto, 1988; Denecke et al., 1991; Fontes et al., 1991). An increase in BiP mRNA and/or protein abundance was observed in tomato seeds treated with calcimycin or tunicamycin after priming, and calcimycin treatments also resulted in an increase in seed longevity equivalent to that induced by heat shock (Figs. 3-5). In addition, calcimycin did not induce accumulation of shsps (Fig. 5B), suggesting that BiP (and possibly other ER chaperones), rather than a more general heat shock response, was involved in increasing the longevity of primed seeds.

As priming apparently acts by initiating metabolic activation and DNA and protein repair processes associated with the early stages of germination (McDonald, 2000), those same processes may result in changes that leave cellular components such as DNA, proteins and membranes vulnerable to more rapid deterioration during storage. In nature, seeds are often exposed to hydration and dehydration cycles, making it likely that mechanisms exist for seeds to adapt to dehydration following a hydration episode. A reduction in seed moisture content may trigger such adaptive responses, some components of which may overlap with adaptive responses to heat and other stresses. Thus, postpriming treatments may act by invoking tolerance mechanisms such as $\mathrm{BiP}$, other hsps and chaperones that may be distinct from those employed normally during programmed dehydration following seed maturation, but which are effective in preserving cells that are dried from a more activated state following hydration and the initiation of germinative metabolism.

\section{Literature Cited}

Alvarado, A.D. and K.J. Bradford. 1988. Priming and storage of tomato (Lycopersicon lycopersicum) seeds. I. Effects of storage temperature on germination rate and viability. Seed Sci. Technol. 16:601-612.

Alvim,F.C.,M.B.Carolino,J.C.M.Cascardo,C.C.Nunes, C.A. Martinez, W.C. Otoni, and P.B. Fontes. 2001. Enhanced accumulation of BiP in transgenic plants confers tolerance to water stress. Plant Physiol. 126:1042-1054.
Association of Official Seed Analysts. 1992. Seedling evaluation handbook. Hdbk. Seed Testing Contrib. 35. Assn. Official Seed Analysts, Las Cruces, N.M.

Arora, R., D.S.Pitchay, and B.C. Bearce.1998. Water-stress induced heat tolerance in geranium leaf tissues: A possible linkage through stress proteins? Physiol. Plant. 103:24-34.

Bentsink, L., C. Alonso-Blanco, D. Vreugdenhil, K. Tesnier, S.P.C. Groot, and M. Koornneef. 2000. Genetic analysis of seed soluble oligosaccharides in relation to seed storability of Arabidopsis. Plant Physiol. 124:15951604.

Bernal-Lugo, I. and A.C. Leopold. 1995. Seed stability during storage: Raffinose content and seed glassy state. Seed Sci. Res. 5:75-80.

Borkird, C., C. Simoens, R. Villarroel, and M. Van Montagu. 1991. Gene expression associated with water-stress adaptation of rice cells and identification of two genes as hsp70 and ubiquitin. Physiol. Plant. 82:449-457.

Bolliger, L., O. Deloche, B.S. Glick, C. Georgopoulos, P. Jeno, N. Kronidou, M. Horst, N. Morishima, and G. Schatz. 1994. A mitochondrial homolog of bacterial GrpE interacts with mitochondrial hsp70 and is essential for viability. EMBO J. 13:1998-2006.

Boubriak, I., V. Vaunemko, L. Lyne, and D.J. Osborne. 2000. Loss of viability in rye embryos at different levels of hydration: senescence with apoptotic nucleosome cleavage or death with random DNA fragmentation, p. 205-214. In: M. Black, K.J. Bradford, and J. Vázquez-Ramos (eds.). Seed biology: Advances and applications. CABIIntl., Wallingford, U.K.

Bray, E.A., T.-Y. Shih, M.S. Moses, A. Cohen, R. Imai, and A.L. Plant. 1999. Water-deficit induction of a tomato H1 histone requires abscisic acid. Plant Growth Regulat. 29:35-46.

Bruggink, G.T., J.J.J. Ooms, and P. van der Toorn. 1999. Induction of longevity in primed seeds. Seed Sci. Res. 9:49-53.

Buitink, J., M.A. Hemminga, and F.A. Hoekstra. 2000. Is there a role for oligosaccharides in seed longevity? An assessment of intracellular glass stability. Plant Physiol. 122:1217-1224.

Cascardo, J.C.M., R.S. Almeida, R.A.A. Buzeli, S.M.B. Carolino, W.C. Ontoni, and E.P.B. Fontes. 2000. The phosphorylation state and expression of soybean BiP isoforms are differentially regulated following abiotic stresses. J. Biol. Chem. 275:14494-14500.

Chiatante, D. and E. Onelli. 1993. Nuclear proteins and the onset of cell proliferation in root meristems of Pisum sativum: QP47 a novel acidic protein. Seed Sci. Res. 3:35-42.

Davis, B.J. 1964. Disc electrophoresis 1l. Method and application to human serum proteins. Ann. N.Y. Acad. Sci. 121:404-427.

Denecke, J., M.H.S. Goldman, J. Demolder, J. Seurinck, and J. Botterman. 1991. The tobacco luminal binding protein is encoded by a multigene family. Plant Cell 3:1025-1035.

DeRocher, A.E. and E. Vierling. 1994. Developmental control of small heat-shock protein expression during pea seed maturation. Plant J. 5:93102.

DuPont, F.M, W.J. Hurkman, C.K. Tanaka, and R. Chan. 1998. BiP, HSP70, NDK and PDI in wheat endosperm. I. Accumulation of mRNA and protein during grain development. Physiol. Plant. 103:70-79.

Figueiredo, J.E.F., J.C.M. Cascardo, S.M.B. Carolino, F.C. Alvim, and E.P.B. Fontes. 1997. Water-stress regulation and molecular analysis of the soybean BiP gene family. Rev. Brasil. de Fisiol. Vege. 9:103-110.

Fontes, E.B.P., B.B. Shank, R.L. Wrobel, S.P.Moose, G.R. Obrian, E.T. Wurtzel, and R.S. Boston. 1991. Characterization of an immunoglobulin binding protein homolog in the maize floury-2 endosperm mutant. Plant Cell 3:483-496.

Forreiter, C. and L. Nover. 1998. Heat induced stress proteins and the concept of molecular chaperones. J. Biosci. 23:287-302.

Gurusinghe, S.H. and K.J. Bradford. 2001. Galactosyl-sucrose oligosaccharides and potential longevity of primed seeds. Seed Sci. Res. 11:121133.

Haas, I.G. and M. Wable. 1983. Immunoglobulin heavy chain binding protein. Nature 306:387-389.

Hebert, D.N, B. Foellmer, and A. Helenius. 1996. Calnexin and calreticulin promote folding, delay oligomerization and suppress degradation of 
influenza hemagglutainin in microsomes. EMBO J. 15:2961-2968.

Helm, K.W. and R.H. Abernethy. 1990. Heat shock proteins and their mRNAs in dry and early imbibing embryos of wheat. Plant Physiol. 93:1626-1633.

Hurkman, W.J., M.F. DuPont, S.B. Altenbach, A. Combs, R. Chan, C.K. Tanaka, M. Reuveni, and J.E. Bernardin. (1998) BiP, HSP70, NDK and PDI in wheat endosperm. II. Effects of high temperature on protein and mRNA accumulation. Physiol. Plant. 103:80-90.

Jones, R.L. and D.S. Bush. 1991. Gibberellic acid regulates the level of a $\mathrm{BiP}$ cognate in the endoplasmic reticulum of barley aleurone cells. Plant Physiol. 97:456-459.

Kawana, K., Y. Miyamoto, K. Tanonaka, Y. Han-no, H. Yoshida, M. Takahashi, and S. Taeo. 2000. Cytoprotective mechanism of heat shock protein 70 against hypoxia/reoxygenation injury. J. Mol. Cell. Cardiol. 32:2229-2237.

Kiyosue, T., K. Yamaguchi-Shinozaki, and K. Shinozaki. 1994. Cloning of cDNAs for genes that are early-responsive to dehydration stress (ERDs) in Arabidopsis thaliana L. Identification of three ERDs and HSP cognate genes. Plant Mol. Biol. 25:791-798.

Kuznetsov, G., L. Bo Chen, and S.K. Nigam. 1997. Multiple molecular chaperones complex with misfolded large oligomeric glycoproteins in the endoplasmic reticulum. J. Biol. Chem. 272:3057-3063.

Laemmli, U.K. 1970. Cleavage of structural proteins during the assembly of the head of bacteriophage T4. Nature 227:680-685.

Leborgne-Castel, N.,P.W.M.Edith, J. Dooren, A.J.Crofts, and L. Denecke. 1999. Overexpression of BiP in tobacco alleviates endoplasmic reticulum stress. Plant Cell 11:459-469.

Lee, G.J., N. Pokala, and E. Vierling. 1995. Structure and in vitro molecular chaperone activity of cytosolic small heat-shock proteins from pea. J. Biol. Chem. 270:10432-10438.

Lee, G.J. and E. Vierling. 2000. A small heat shock protein cooperates with heat shock protein 70 systems to reactivate a heat-denatured protein. Plant Physiol. 122:189-197.

Leprince, O., G.A.F. Hendry, and B.D. McKersie. 1993. The mechanism of desiccation tolerance in developing seeds. Seed Sci. Res. 3:231-246.

Li, L.J., X. Li, A. Ferrario, N. Rucker, E.S. Liu, S. Wong, C.J. Gomer, and A.S. Lee. 1992. Establishment of chinese hamster ovary cell line that expresses grp78 antisense transcripts and suppresses A23187 induction of both grp78 and grp94. J. Cell. Physiol. 153:575-582.

Li, W.W.F., S. Alexandre, X.J. Cao, and A.S. Lee. 1993. Transactivation of the grp78 promoter by $\mathrm{Ca}^{2+}$ depletion. A comparative analysis with A23187 and the endoplasmic reticulum $\mathrm{Ca}^{2+}$-ATPase inhibitor thapsigargin. J. Biol. Chem. 268:12003-12009.

Li, X. and A.S. Lee. 1991. Competitive inhibition of a set of endoplasmic reticulum protein genes (GRP78, GRP94 and Erp72) retards cell growth and lowers viability after ionophore treatment. Mol. Cell. Biol. 11:34463453.

Lievremont, J.P., R. Rizzuto, L. Hendershot, and J. Meldoles. 1997. BiP, a major chaperone protein of the endoplasmic reticulum lumen, plays a direct and important role in the storage of the rapidly exchanging pool of $\mathrm{Ca}^{2+}$. J. Biol. Chem. 272:30873-30879.

McDonald, M.B. 2000. Seed priming, p. 287-325. In: M. Black and J.D. Bewley (eds.). Seed technology and its biological basis. Sheffield Acad. Press, Sheffield, U.K.

Meyer, D.J. 1995. Genetic and biochemical characterization of the endoplasmic reticulum-localized molecular chaperone BiP in Lycopersicon esculentum. PhD diss. Univ. Calif., Davis.

Miskovic, D. and J.J. Heikkila. 1999. Constitutive and stress-inducible expression of the endoplasmic reticulum heat shock protein 70 gene family member, immunoglobulin-binding protein (BiP), during Xenopus laevis early development. Dev. Gen. 25:31-39.

Mkrtchian, S., C. Fang, U. Hellman, and M. Ingelman-Sundberg. 1998. A stress-induced rat liver endoplasmic reticulum protein, ERp29. Euro. J. Biochem. 251:304-313.

Munro, S. and H.R.B. Pelham. 1986. An Hsp70-like protein in the ER; identity with the $78 \mathrm{kd}$ glucose-regulated protein and immunolglobulin heavy chain binding protein. Cell 46:291-300.

Ni, B.R. and K.J. Bradford. 1993. Germination and dormancy of abscisic acid- and gibberellin-deficient mutant tomato (Lycopersicon esculentum Mill.) seeds. Sensitivity of germination to abscisic acid, gibberellin and water potential. Plant Physiol. 101:607-617.

Nover, L. and K-D. Scharf. 1997. Heat stress proteins and transcription factors. Cell. Mol. Life Sci. 53:80-103.

Parsell, D.A. and S. Lindquist. 1993. The function of heat-shock proteins in stress tolerance: degradation and reactivation of damaged proteins. Annu. Rev. Genet. 27:437-496.

Reddy, K.R., S. Chaudhary, P. Patil, and P. Krishnar. 1998. The 90 kDa heat shock protein (hsp90) is expressed throughout Brassica napus seed development and germination. Plant Sci. 131:131-137.

Sambrook, J.,E.F. Fritsch, and T. Maniatis (eds.). 1989. Molecular cloning: A laboratory manual. $2^{\text {nd }}$ ed. Cold Spring Harbor Laboratory Press, Cold Spring Harbor, N.Y.

Schipper, J., P. van der Toorn, and T. Bruggink. 2001. Process for prolonging the shelf life of primed nongerminated seeds. US Patent No. 6,313,377 B1.

Schöffl, F., R. Prändl, and A. Reindl. 1998. Regulation of the heat-shock response. Plant Physiol. 117:1135-1141.

Scippa, G.S., A. Griffiths, D. Chiatante, and E.A. Bray. 2000. The H1 histone variant of tomato, H1-S, is targeted to the nucleus and accumulates in chromatin in response to water-deficit stress. Planta 211:173-181.

Tarquis, A.M. and K.J. Bradford. 1992. Prehydration and priming treatments that advance germination also increase the rate of deterioration of lettuce seeds. J. Expt. Bot. 43:307-317.

Taylor, A.G., P.S. Allen, M.A. Bennett, K.J. Bradford, J.S. Burris, and M.K. Misra. 1998. Seed enhancements. Seed Sci. Res. 8: 245-256.

Techel, D., T. Hafker, S. Muschner, M. Reimann, Y. Li, C. Monnerjahn, and L. Rensing. 1998. Molecular analysis of glucose-regulated gene (grp78) of Neurospora crassa. Biochim. Biophys. Acta 1397:21-26.

van Gemeran, I.A., P.J. Punt, A. Drint-Kuyvenhoven, M.P. Broekhuijsen, A. van't Hoog, A. Beijersbergen, C.T. Verrips, and C.A.M.J.J. van den Hondel. 1997. The ER chaperone encoding bipA gene of black Aspergilli is induced by heat shock and unfolded proteins. Gene 198:43-52.

Vierling, E. 1997. The small heat shock proteins in plants are members of an ancient family of heat induced proteins. Acta Physiol. Plant. 19:539_ 547.

Walters, C. 1998.Understanding the mechanisms and kinetics of seed aging. Seed Sci. Res. 8:223-244.

Watowich, S.S. and R.I. Morimoto. 1988. Complex regulation of heatshock and glucose-responsive genes in human cells. Mol. Cell Biol. 8:393-405.

Wehmeyer, N. and E. Vierling. 2000. The expression of small heat shock proteins in seeds responds to discrete developmental signals and suggests ageneral protective role in desiccation tolerance. Plant Physiol. 122:1099_ 1108.

Wisniewski, M., T.J. Close, A. Timothy, and R. Arora. 1996. Seasonal patterns of dehydrins and 70-kDa heat-shock proteins in bark tissues of eight species of woody plants. Physiol. Plant. 96:496-505.

Wolkers, W.F., M. Alberda, M. Koornneef, K.M. Leon-Kloosterziel, and F.A. Hoekstra. 1998. Properties of proteins and the glassy matrix in maturation-defective mutant seeds of Arabidopsis thaliana. Plant J. 16:133-143

Wolkers, W.F., F.A.A. Tetteroo, M. Alberda, and F.A. Hoekstra. 1999. Changed properties of cytoplasmic matrix associated with desiccation tolerance of dried carrot somatic embryos. An in situ Fourier transform infrared spectroscopic study. Plant Physiol. 120:153-163.

Wooden, S.K., L.J.Li, D. Navarro, I. Qadri, L. Pereira, and A.S. Lee. 1991. Transactivation of the grp78 promoter by malfolded proteins, glycosylation block, and calcium ionophore is mediated through a proximal region containing a CCAAT motif which interacts with CTF/NF-I. Mol. Cell. Biol. 11:5612-5623.

Wu, C., J. Clos, G. Giorgi, R.I. Haroun, S.-J. Kim, S.K. Rabindran, J.T. Westwood, J. Wisniewski, and G. Yim. 1994. Structure and regulation of heat shock transcription factor, p. 395-416. In: R.I. Morimoto, A. Tissieres, and C. Georgopoulos (eds.). The biology of heat shock proteins and molecular chaperones. Cold Spring Harbor Laboratory Press, Plainview, N.Y. 